\title{
Development of Iridium Oxide Sensor for Surface pH Measurement of a Corroding Metal under Deposit
}

\author{
Jalal Rouhi ${ }^{1}$, Saeid Kakooei ${ }^{2, *}$, Mokhtar Che Ismail $^{2}$, Rouhollah Karimzadeh $^{l}$, \\ Mohamad Rusop Mahmood ${ }^{3}$ \\ ${ }^{1}$ Department of Physics, Shahid Beheshti University, Evin, Tehran 19839, Iran \\ ${ }^{2}$ Centre for Corrosion Research, Department of Mechanical Engineering, Universiti Teknologi \\ PETRONAS, Tronoh31750, Malaysia \\ ${ }^{3}$ Centre of Nanoscience and Nanotechnology (NANO-SciTech Centre), Institute of Science, Universiti \\ Teknologi MARA, Shah Alam, Selangor 40450, Malaysia \\ *E-mail: skakooei59@ hotmail.com, saeid.kakooei@utp.edu.my
}

doi: $10.20964 / 2017.11 .07$

Received: 29 May 2017 / Accepted: 21 August 2017 / Published: 12 October 2017

A novel method used to design and fabricate a $\mathrm{pH}$ sensor for measurement of hydrogen ion activity on corroding metal surface in under deposit. The electrodeposition method of cyclic voltammetry approach is used for coating of Iridium Oxide $\left(\mathrm{IrO}_{\mathrm{X}}\right)$ on stainless steel substrate. The $\mathrm{pH}$ value of the X52 carbon steel under deposit (agar) was monitored for the first time using the in-situ iridium oxide $\mathrm{pH}$ probe during the $\mathrm{CO}_{2}$ corrosion at 25 and $80^{\circ} \mathrm{C}$. Cyclic voltammetry $(\mathrm{CV})$, field emission scanning electron microscopy (FESEM), energy-dispersive X-ray spectroscopy (EDX), Linear polarization resistance (LPR), and open circuit potential (OCP) were used for $\mathrm{CO}_{2}$ corrosion and iridium oxide film characterization. The fabricated $\mathrm{pH}$ sensor was calibrated by using a commercial glass $\mathrm{pH}$ probe. The response of electrodeposited $\mathrm{IrO}_{\mathrm{X}}$ electrodes to exposure to a series of universal buffer solutions depicts a linear super-Nernstian response resulting in a sensitivity of $-77.18 \mathrm{mV} / \mathrm{pH}$ for combination of three $\mathrm{IrO}_{\mathrm{X}} \mathrm{pH}$ sensors. The $\mathrm{pH}$ response measured by $\mathrm{OCP}$ at $25^{\circ} \mathrm{C}$ was $75.3 \mathrm{mV} / \mathrm{pH}$ units. The $\mathrm{pH}$ of metal surface under deposit increased gradually up to $\mathrm{pH}=8$ after exposure in $\mathrm{CO}_{2}$-saturated $3 \%$ $\mathrm{NaCl}$ solution compared to the bulk solution $\mathrm{pH}(\mathrm{pH}=6)$. Results demonstrated the proposed $\mathrm{pH}$ sensor design can be used for real-time corrosion monitoring by surface $\mathrm{pH}$ measurement. The design approves that the measurement was able to determine the $\mathrm{pH}$ changes under agar, which is a critical requirement for studying corrosion under deposit. In all cases, metal surface $\mathrm{pH}$ under deposit increased compared with bulk solution $\mathrm{pH}$ after the corrosion process began. These findings indicate that $\mathrm{IrO}_{\mathrm{X}} \mathrm{pH}$ sensor material can be changed to any other sensing material which is very useful for monitoring of MIC or other kind of corrosion.

Keywords: $\mathrm{IrO}_{\mathrm{X}} \mathrm{pH}$ sensor; Electrodeposition method; Surface $\mathrm{pH}$ measurement; Cyclic voltammetry 


\section{FULL TEXT}

(C) 2017 The Authors. Published by ESG (www.electrochemsci.org). This article is an open access article distributed under the terms and conditions of the Creative Commons Attribution license (http://creativecommons.org/licenses/by/4.0/). 